Original Research Paper

\title{
Prevalence and Genotypic Analysis and Antibiotic Resistance of Salmonella Species Isolated from Imported and Freshly Slaughtered Chicken
}

\author{
${ }^{1}$ Wael K. Elfeil, ${ }^{2}$ Mahmoud E. Ezzat, ${ }^{4}$ Amira Fathi, \\ ${ }^{2}$ Mennat-Allah A. Alkilany and ${ }^{3}$ Reham R. Abouelmaatti \\ ${ }^{I}$ Department of Avian and Rabbit Medicine, Faculty of Veterinary Medicine, Suez Canal University, Ismailia, Egypt \\ ${ }^{2}$ Department of Bacteriology, Immunology and Mycology, \\ Faculty of Veterinary Medicine, Suez Canal University, Ismailia, Egypt \\ ${ }^{3}$ Microbiology Unit, Reference Laboratory for Veterinary Quality Control on Poultry Production, Mansoura Branch, Egypt \\ ${ }^{4}$ Department of Biochemistry, Norman Bethune College of Medicine, Jilin University Changchun, Jilin, China
}

\author{
Article history \\ Received: 17-07-2019 \\ Revised: 09-01-2020 \\ Accepted: 22-05-2020 \\ Corresponding Author: \\ Mahmoud E. Ezzat \\ Department of Bacteriology, \\ Immunology and Mycology, \\ Faculty of Veterinary \\ Medicine, Suez Canal \\ University, Ismailia, Egypt \\ Email: ezzat.scu@gmail.com
}

\begin{abstract}
Salmonellosis is a bacterial disease caused by different types of Salmonella species and associated with clinical disease in both human, birds and livestock species. Salmonellosis associated with severe economic impacts either from losses in poultry farm due to pathological picture losses, cost of medication, condemnation in slaughterhouse or zoonotic important. This study focused on the prevalence of Salmonellae in imported frozen and freshly slaughtered chicken in Dakahlia Governorate, Egypt. A total of 273 samples were collected from 66 examined birds (24 from Balady chickens "Native Bred", 23 from Broiler chicken and 19 from frozen chicken). Nineteen out of 66 chickens (6.95\%) Salmonella species were isolated, representing: 10 from Balady (native bred) chicken $(8.3 \%)$, eight from broiler chicken $(7 \%)$ and one from imported frozen chicken (2.61\%). The serotyping of the Salmonellae isolated from chickens as follow (5) (26.3\%) S. typhimurium, (5) (26.3\%) S. kentucky, (3) (15.8\%) S. infantis (2) (10.5\%) S. enteritidis, (2) (10.5\%) S. tamale, (2) (10.5\%) S. newport. PCR assay was carried out on nine serovars (2) S. enteritidis, (2) S. typhimurium, (2) S. kentucky, (1) S. infantis, (1) S. tamale, (1) S. newport detect the presence of InvA (invasion protein InvA), bla aac C (Aminoglycoside N (3)-acetyltransferase IV), qepA (Quinolone efflux pump), tetA(A) (Tetracycline resistance protein, class D) and sull(Dihydropteroate synthase type-1) genes, the percentage respectively was $100 \%$, 100\%, 33.3, 33.3\%, 88.89\%, $77.78 \%$ in examined Salmonella strains. The susceptibility of Salmonella serovars to chemotherapeutic agents showed high sensitivity to levofloxacin and gentamycin, but the highest resistance was to sulfamethoxazole. The increased prevalence rate of Salmonella species isolation from chicken and chicken meat carrying Multidrug Resistance (MDR) genes for commonly used antimicrobial agents, consider a critical threat for public health issues. Further studies are required to understand Salmonella spp epidemiology and to limit the spread of multidrug-resistant types.
\end{abstract}

Keywords: Salmonella, Fresh Chicken, Frozen Meat, Food Poisoning

\section{Introduction}

Salmonellosis is a significant global public health issue and causes high morbidity rate and has a significant economic impact. Foodborne diseases persist in many countries and consider the most important public health problem. There is global improvement in food processing practices, hygiene measures, education of food handlers on the potential risks and information to consumers for proper utilization, but still so far to 
eliminate the foodborne pathogen problem (Ruban et al., 2010). Infection with Salmonellae is still the first reported cause of bacterial foodborne illness all over the world and associated with gastroenteritis disorders (Huong et al., 2006; WHO, 2004). Chicken meat Contaminated by Salmonellae is the most significant potential hazard of human gastroenteritis worldwide; as several reports correlate the human salmonellosis cases to the consumption of contaminated chicken meat and byproducts with different salmonella species (Beli et al., 2001). The majority of human salmonellosis infections are derived from the consumption of contaminated chicken meat, although there are several other transmission routes of infection (Hassanein et al., 2011). Contaminated frozen chicken products and byproducts have been considered potential source for salmonellosis; where the presence of Salmonella species in frozen chicken products maybe associated with potential infection risk to human if the product is improperly cooked (Dominguez and Schaffner, 2009). Chicken stored at variable temperatures and chickens brought from wet markets has higher levels of salmonella than those brought from other hygienic retail store; also, chickens produced by integrated companies have lower levels of salmonella than non-integrated companies due to higher biosecurity measures (Donado-Godoy et al., 2014). The risk of salmonellosis from chilled chickens higher than frozen chicken carcasses, which may associate to the preparation practices and hygienic measures (Donado-Godoy et al., 2012). Antibiotics administration is an important tool in the reduction the incidence and mortalities associated with avian salmonellosis (Duarte et al., 2009). The recent reports highlighted the increased rate of MDR salmonella species which may correlate to the massive and improper usage of antimicrobial agents in human and veterinary medicine and it represent a global public health problem (Cruchaga et al., 2001; Mosalem, 2016) (Eid et al., 2016; Elfeil et al., 2016; Enany et al., 2018). The problem of MDR salmonella spread all over the world with higher prevalence rate in in the developing nations with no clear prevalence mapping to such genes (Eid et al., 2019). The studying of drug resistance and MDR patterns between the different Salmonella strains gives not only important evidence to the clinician for the best therapeutic regime and suitable choices to control the reported cases but also an important tool in devising and scheduling a proper chemoprophylactic and chemotherapeutic drug regimens within a geographical area and highlighted the need for developing suitable antimicrobial agents against certain pathogen (Abouelmaatti et al., 2013; Elfeil et al., 2012; Murugkar et al., 2005). In Egypt, Salmonella reported the highest rate of foodborne infection via chicken's meat (WHO, 2004; 2007). The problem in Egypt is old where; a prevalence survey has been conducted on year 1979 at upper Egypt region (Assiut, New-Valley and Suhag Governorates) and examined bacteriologically dead chickens and ducks as well as 2325 fecal swabs from living chickens and ducks suffered from paratyphoid infections; they isolated 17 Salmonella serotypes, where the most common types were $S$. hessarek, S. orian and S. miami (Bayoumi et al., 1979). Moreover, In Belbais El-Sharkia Governorate, another prevalence report applied on 1989 and has been recorded salmonella isolation from $10.7 \%$ of chickens and ducks in contact with human diarrheic cases (Taha, 1989) that similar to other prevalence report in east Egypt regions applied on 2016 and recorded salmonellae isolation from $10.5 \%$ and $14.3 \%$ of chicken and pigeon in contact with human diarrheic cases (El-Demerdash et al., 2016). In Dakahlia Governorate, salmonella species were isolated from $13.3 \%$ of chickens of different ages from farms in Bilkas and Gamasa (Moawad, 2009). While in Alexandria governorate, salmonella species were isolated from layer flocks in poultry farms with a percentage of $11.4 \%$ (Draz et al., 1997). Lower percentages than the previously mentioned were reported by Sadoma, (1997) who isolated Salmonellae from six out of 300 (2\%) cloacal swabs collected from 30 chicken farms at different localities in Gharbia (Sadoma, 1997). Nabil and Yonis (1999) isolated S. typhimurium, S. anatum and S. pullorum from $2.5 \%$ of chickens and $4 \%$ of ducks samples from fattening and laying farms in Kafr El-Shaikh Governorate and Ahmed et al. (2009); isolated salmonella from chickens reared in a rural village in El-Sharkia province with a percentage of $1.7 \%$; the serotyping study of the isolated strains showed that they were grouped into two different serogroups, $S$. enteritidis and S. typhimurium constituting $80 \%$ and $20 \%$, respectively. A study was performed in Qalyubia governorate, Egypt and highlighted the prevalence of $S$. kentucky, S. infantis, S. enteritidis, S. typhimurium, S. chiredzi and $S$. tsevie in commercial broiler chicken flocks (El-Ghany et al., 2012). This study focused on examining random samples from different stores and slaughter houses and examine the prevalence of different salmonella species in frozen and freshly slaughtered chicken's mean and check the presence of antimicrobial resistant, MDR and virulence genes in collected isolates, which can seriously affect the human health and the medication regime and can return again to poultry farms through works in the poultry industry.

\section{Materials and Methods}

\section{Sample Collection}

A total of 273 samples (235) from freshly slaughtered and (38) from imported frozen chickens were aseptically 
collected from birds' markets in Dakahlia Governorate, Egypt. The samples were (liver, cecum, lung, breast muscle and thigh muscle). All samples were collected in sterile plastic bags and transferred immediately in icebox to Reference Laboratory for Veterinary Quality Control on Poultry Production for bacteriological examination.

\section{Isolation of Salmonella}

The collected samples weighted then inoculated in buffered peptone water (1:10 dilution) then incubated at $37 \pm 1^{\circ} \mathrm{C}$ for $16-20 \mathrm{~h}$ According to ISO 6579 (2002). The pre-enrichment broth was mixed after incubation, then sub culture in two different broths; where $0.1 \mathrm{~mL}$ of the broth was transferred into a tube containing $10 \mathrm{~mL}$ of Rappaport-Vassiliadis medium with soya (RVS broth) and incubated at $41.5^{\circ} \mathrm{C}$ for $24 \mathrm{~h}$; another $0.1 \mathrm{~mL}$ of the pre-enrichment broth was transferred into a tube has 10 $\mathrm{mL}$ of Muller-Kauffmann Tetrathionate-Novobiocin, broth (MKTTn broth) and incubated at $37^{\circ} \mathrm{C}$ for $24 \mathrm{~h}$. After incubation, a loop-full of the RVS and MKTTn broth were streaked separately onto the surface of Xylose Lysine Deoxycholate Agar (XLD agar) and Hektoen Enteric (HE agar). The plates were incubated in an inverted position at $37^{\circ} \mathrm{C}$ for $24 \mathrm{~h}$ then checked for growth of typical Salmonella colonies. Typical colonies of Salmonella grow on XLD agar with a black center and a lightly transparent zone of reddish color due to the color change of the indicator. Lactose-positive Salmonella is yellow with or without blackening on XLD agar. On HE colonies appeared as deep blue.

\section{Biochemical Identification}

Purified isolates were examined by different biochemical reactions According to ISO 6579 (2002) either by oxidase, urea hydrolysis, $\mathrm{H}_{2} \mathrm{~S}$ production on TSI, lysine decarboxylation, citrate utilization and indole as shown in Table 1.

\section{Serogrouping of Salmonella}

The isolates that were identified biochemically as Salmonella were subjected to serological identification according to Kauffman-White Scheme (Kauffmann, 1972) for determination of somatic (O) and flagellar (H) antigens (Cruickshank, 1975).

\section{Antimicrobial Susceptibility Testing}

The pure identified Salmonella strains were tested for antimicrobial susceptibility; where the test was done by the agar disc diffusion method as previously described (Finegold and Martin, 1982).

\section{Detection of Virulence Genes and Antibiotics Resistance Genes}

The purified salmonella isolates subjected to DNA Extraction using QIAamp DNA mini kit (Qiagen, Germany) according to manufacturer's instructions. the extracted DNA subjected to PCR screening for the presence of selected virulence and antimicrobial resistant genes using specific Oligonucleotide primers sets listed in Table 2.

Table 1: Biochemical identification of suspected Salmonella species

\begin{tabular}{|c|c|c|}
\hline Biochemical test & Reaction & Result \\
\hline Oxidase reaction & Negative & Colorless \\
\hline Urease hydrolysis test & Negative & Yellow (Medium remain original yellow) \\
\hline $\mathrm{H} 2 \mathrm{~S}$ production in Triple sugar iron agar (TSI) & Positive & $\begin{array}{l}\text { Alkaline (red) slant, acid (yellow) butt with or without } \\
\text { - blackening due to } \mathrm{H} 2 \mathrm{~S} \text { production. }\left(\mathrm{k} / \mathrm{A} / \mathrm{G} / \mathrm{H}_{2} \mathrm{~S}\right)\end{array}$ \\
\hline Lysine decarboxylation test & Positive & Purple color with $\mathrm{H} 2 \mathrm{~S}$ at the middle of the tube \\
\hline Citrate utilization & Positive & Development of deep blue color within $24-48 \mathrm{~h}$ \\
\hline Indole reaction & Negative & Yellow ring. \\
\hline
\end{tabular}

Table 2: Oligonucleotide primers sequences Source

\begin{tabular}{|c|c|c|c|}
\hline Primer & Sequence & Amplified product & Reference \\
\hline \multirow[t]{2}{*}{$\operatorname{tet} A(A)$} & GGTTCACTCGAACGACGTCA & $576 \mathrm{bp}$ & Randall et al. (2004) \\
\hline & CTGTCCGACAAGTTGCATGA & & \\
\hline \multirow[t]{2}{*}{ bla $_{T E M}$} & ATCAGCAATAAACCAGC & $516 \mathrm{bp}$ & Colom et al. (2003) \\
\hline & CCCCGAAGAACGTTTTC & & \\
\hline \multirow[t]{2}{*}{ aacC } & GGCGCGATCAACGAATTTATCCGA & $448 \mathrm{bp}$ & Lynne et al. (2008) \\
\hline & CCATTCGATGCCGAAGGAAACGAT & & \\
\hline \multirow[t]{2}{*}{ sull } & CGGCGTGGGCTACCTGAACG & $433 \mathrm{bp}$ & Ibekwe et al. (2011) \\
\hline & GCCGATCGCGTGAAGTTCCG & & \\
\hline \multirow[t]{2}{*}{ qерA } & CGTGTTGCTGGAGTTCTTC & $403 \mathrm{bp}$ & Cattoir et al. (2008) \\
\hline & CTGCAGGTACTGCGTCATG & & \\
\hline \multirow[t]{2}{*}{$\operatorname{inv} A$} & GTGAAATTATCGCCACGTTCGGGCAA & $284 \mathrm{bp}$ & de Oliveira et al. (2006) \\
\hline & TCATCGCACCGTCAAAGGAACC & & \\
\hline
\end{tabular}




\section{Results and Discussion}

Poultry industry suffer from several pathogen threats in Egypt either bacterial like Salmonella, Pasteurella, Clostridium or viral types like Avian influenza virus (AIV), Newcastle Disease Virus (NDV), Infectious Bronchitis Virus (IBV), Infectious Bursal Disease Virus (IBDV) or parasitic as coccidia and it associated with severe economic on the industry and human public heath impact (Algammal and Elfeil, 2015; Ayoub et al., 2019; Diab et al., 2019; Eid et al., 2016; 2019; Elhady et al., 2018; Sedeik et al., 2018; 2019; Sultan et al., 2019a; 2019b). Salmonella consider one of the major bacterial threats affect poultry industry and associated with severe economic losses. In this study, 66 birds, (24) from Balady chickens, (23) Broiler chickens and (9) Frozen chickens were examined for the presence of Salmonella; the number and percentage of positive samples from Balady chickens" Native breed" (10;8.3\%), Broiler chickens $(8 ; 7 \%)$ and Frozen chickens $(1 ; 2.61 \%)$; where the highest percentage of Salmonella isolation was from Balady chickens, while the lowest percentage was from frozen chickens (Table 3). The obtained results matched with other reports describing the prevalence of salmonella in chicken and chicken products in other Egyptian governorates, where Ezzat et al. (2014); who found that Salmonella species isolates, representing: $7.5 \%$ from apparently healthy chicken in east Egypt regions and Ibrahim et al. (2013); who highlighted the Salmonella species occurrence as $9-10 \%$ in examined breeders flocks; Rabie et al. (2012); who reported the prevalence of Salmonella was 14\% and 4\% in chickens and raw chickens meat respectively in Toukh, Egypt and Hassanein et al. (2011); reported 52\% of frozen chicken fillet and 36\% of frozen chicken leg samples in Assiut, Egypt and the identified dominant serovar was $S$. enteritidis. The obtained data agreed with other reports outside Egypt, as in brazil Medeiros et al. (2011), isolated Salmonella in $0.0-8.9 \%$ from the collected chicken carcass parts and Le Bouquin et al. (2010); who carried out a nation-wide survey in France on the period from October 2005 to September 2006 and examined 370 randomly selected French commercial broiler chicken flocks to determine the prevalence of different Salmonella species and the results showed prevalence of different serotypes in $8.6 \%$ of the examined flocks. In Croatia, a study highlighted isolation of Salmonella from 66 samples of fresh, retail-cut chicken meat and frozen ground chicken meat with $10.6 \%$ incidence among the examined samples (Kozačinski et al., 2006). In Pakistan, Soomro et al. (2010); recorded Salmonella species in Hyderabad, Pakistan of $38 \%$ from poultry meat retail markets. Regarding post slaughter carriage rates the obtained results matched with previous reports in different countries, where; Chenu et al., (2011); reported that the post slaughter carriage rates of Salmonella on broiler carcasses present with variable rates according to the country and continents with may correlated to the hygienic and processing practice; where the prevalence rate was $36.7 \%$ in Australia; $21 \%$ in the USA and $15.7 \%$ in Europe.; White et al. (2001); who recorded that $3.0 \%$ of the retail examined meat samples (turkey, chicken, beef and pork) were positive for different Salmonella strains in the Greater Washington region, USA; Kaushik et al. (2014); who reported that the incidence of Salmonella in chicken meat samples was $23.7 \%$ in India, Donado-Godoy et al. (2012); who recorded $27 \%$ of the carcasses sampled and Chilled chickens were positive for Salmonella in Colombia; The European Food Safety Authority; carried out a European Union-wide baseline prevalence survey on different strains of Salmonella on broiler carcasses, around 10132-broiler production batches were collected and examined from around 561 slaughterhouses in 26 different European Union (EU) Member States and from two countries not belonging to the EU; the survey analysis showed a salmonella Community prevalence of $15.61 \%$ with wide margin of variation in between the different EU states $(0.0 \%$ to $26.6 \%)$ and in one state the prevalence rate reach $85.61 \%$ in the examined samples and the most predominant serotypes was $S$. infantis (Authority, 2010).

Salmonella strains were serotyped using poly and monovalent "O" and " $\mathrm{H}$ " antisera and the results revealed that 19 strains were serotyped as: $S$. typhimurium $(5 ; 26.3 \%)$, S. kentucky $(5 ; 26.3 \%), S$. infantis $(3 ; 15.8 \%)$, S. enteritidis $(2 ; 10.5 \%)$, S. tamale and $(2 ; 10.5 \%)$ and $S$. newport $(2 ; 10.5 \%)$ as shown in Table 4 . These results vary from country to another, where Medeiros et al. (2011) reported different percentage in brazil where S. enteritidis $(48.82 \%), S$. infantis (7.6\%) and S. typhimurium (7.2\%) from chicken, Ezzat et al. (2014); who reported that the serotyping of the Salmonellae from chickens were $(8 ; 21.6 \%) \mathrm{S}$. enteritidis, $(5 ; 13.5 \%)$ S. kentucky, (2; 5.4\%) S. newport, were isolated from broilers. Where in EU; baseline Community prevalence survey of Salmonella showed the most predominate serotypes in broiler carcass was Salmonella infantis and Salmonella enteritidis and accounted as $1 / 3$ and $1 / 6$ of the Salmonella isolates, respectively (Authority, 2010); in France, Le Bouquin et al. (2010); reported that the most prevailing serovar was $S$. hadar followed by $S$. mbandaka and $S$. anatum ; while in Pakistan, Soomro et al. (2010); reported the most prevailing serogroups among chickens were $S$. typhi, $S$. enteritidis, $S$. typhimurium and $S$. pullorum. 
Mahmoud E. Ezzat et al. / American Journal of Animal and Veterinary Sciences 2020, 15 (2): 134.144 DOI: 10.3844/ajavsp.2020.134.144

Table 3: Incidence of Salmonella isolation from chickens

\begin{tabular}{llccc}
\hline Types of chicken meat & Types of samples & No. of examined samples & No. of positive samples & Proportion \\
\hline Balady chicken & Liver & 24 & 2 & 8.30 \\
& Cecum & 24 & 2 & 8.30 \\
& Lung & 24 & 2 & 8.30 \\
& Breast & 24 & 2 & 8.30 \\
& Thigh & 24 & 2 & 8.30 \\
Broiler chicken & Total & 120 & 10 & 8.30 \\
& Liver & 23 & 2 & 8.70 \\
& Cecum & 23 & 2 & 8.70 \\
& Lung & 23 & 0 & 0.00 \\
Frozen chicken & Breast & 23 & 2 & 8.70 \\
& Thigh & 23 & 2 & 8.70 \\
Total & Total & 115 & 8 & 7.00 \\
& Breast & 19 & 1 & 5.26 \\
& Thigh & 19 & 0 & 0.00 \\
& Total & 38 & 1 & 2.60 \\
\end{tabular}

Table 4: Numbers and percentage of different serotypes of Salmonellae isolated from chickens

Isolated serotypes

\begin{tabular}{lcc}
\hline Serotype & No. of serotypes & $\%$ \\
\hline S. Typhimurium & 5 & 26.3 \\
S. Enteritidis & 2 & 10.5 \\
S. Kentucky & 5 & 26.3 \\
S. Infantis & 3 & 15.8 \\
S. Tamale & 2 & 10.5 \\
S. Newport & 2 & 10.5 \\
Total & 19 & 100.0 \\
\hline
\end{tabular}

Regarding antimicrobial resistant among the examined 19 different salmonella isolates; the highest resistant to sulfamethoxazole $(19 / 19 ; 100 \%)$, then resistance to tetracycline and amoxicillin $(15 / 19 ; 78.9 \%)$, resistance to neomycin $(12 / 19 ; 63.2 \%)$, resistance to chloramphenicol $\quad(8 / 19 ; 42.1 \%)$, resistance to doxycycline and colistin $(5 / 19 ; 26.3 \%)$, resistance to ciprofloxacin and gentamycin $(4 / 19 ; 21.1 \%)$ and the lowest resistant was to levofloxacin $(3 / 19 ; 15.8 \%)$ as shown in Table 5. The data obtained from this study nearly in coordinated with Ahmed et al. (2014); who conducted a survey on salmonella MDR genes in Egypt and concluded that 47/69 Salmonella isolates (68.1\%) showed MDR phenotypes to at least three different antimicrobial classes, Yang et al. (2002); who tested 22 S. typhimurium and $14 \mathrm{~S}$. enteritidis isolates from animals and birds at Korea during the period from 1994 to 2001 for their antibiotic patterns and results showed high resistance to sulfisoxazole and tetracycline as $95 \%$ and $86 \%$, respectively, Hui et al. (2015) who reported Salmonella strains resistance to doxycycline $(28.21 \%)$ in central China and Sodagari et al. (2015); who observed in Iran, high antimicrobial resistance to tetracycline was $81 \%$ in Iran. However, the obtained results differ from de Oliveira et al. (2006); who tested The antimicrobial resistance of $79 \mathrm{~S}$. enteritidis isolates from foods including beef meat and poultry meat individually and resistance observed was to gentamycin (12.71\%) and neomycin (17.7\%), Van et al. (2007); who isolated Salmonella from raw food samples including chicken and tested for their susceptibility to antibiotics in Vietnam and recorded that out of 91 serotypes, $40.7 \%$, $22.1 \%$ and $16.5 \%$ were resistant to tetracycline, ampicillin and sulfafurazole respectively, Foley and Lynne (2008); who reported that multidrug resistance for ampicillin, chloramphenicol, sulfonamides, tetracycline and streptomycin was detected in $9.3 \%$ of Salmonella strains tested, Hyeon et al. (2011); who estimated the antibiotic resistance of Salmonellae isolated from chicken meat and the resistance observed to tetracycline and chloramphenicol (16.7\%) in Seoul, South Korea in 2009, Capuano et al. (2013); who reported that none of the isolates were resistant to ciprofloxacin and enrofloxacin, while low resistance to gentamicin, ceftazidime (1.7\% each), cephalothin and Colistin sulfate $(2.6 \%$ each) and most resistance was to ampicillin $(45.6 \%)$, tetracycline $(48.21 \%)$, streptomycin $(52.59 \%)$ and sulfonamides $(53.5 \%)$ in Italy.

PCR is a perfect tool for accurate detection of Salmonella resistant genes revealed that genotypic analysis of Salmonella strains qepA (a resistant gene for quinolones) was reported with a percentage of (3 out of 9 isolates) $33.3 \%$ as in Fig. 1. Our result differs from Silva-Sanchez et al. (2011); who reported that no Salmonella isolates showed the presence of qepA during his study and Lunn et al. (2010); who found that one isolate $(2.4 \%)$ showed the presence of qepA. The bla $a_{\mathrm{TEM}}$ gene, a resistant gene encoded for B- lactamases was reported in this study with a percentage of $100 \%$ in all Salmonella serotypes as in Fig. 2. This result agreed but with higher percentage with previous report as in Canada, the percentage of bla $a_{\text {TEM }}$ gene in Salmonella isolates was $17 \%$ (Aslam et al., 2012), in Korea, $90.5 \%$ penicillin-resistant $S$. Enteritidis carried 
the bla ${ }_{\text {TEM }}$ gene (Hur et al., 2011) and in china, bla TEM gene detected in $51.6 \%$ of 62 ceftriaxone resistant Salmonella isolates (Yang et al., 2010). The tetA-gene, a gene encoded for tetracycline resistance was detected in this study with a percentage of $88.89 \%$ (8 out of 9 isolates) as in Fig. 3. This result nearly in coordinated with Shahada et al. (2006); who reported that in Japan $89 \%$ of oxytetracycline-resistant $S$. Infantis from poultry carried the tet (A) gene, while this result differs from a study performed by Zhang et al. (2011); who recorded the presence of tetA gene in Salmonella isolates from poultry with a percentage of $73.1 \%$ and Ahmed and Shimamoto (2012); who identified tetracycline resistance gene tet A in 14 out of 21 (66.7\%) Salmonella isolates. The sul 1 gene, a gene encoded for sulfonamide resistance was reported in this study with a percentage of $77.78 \%$ (7 out of 9 isolates) as in Fig. 4. This result nearly similar with those of Zou et al. (2009); who detected sul 1 in 11 of 16 isolates with a percentage of $68.7 \%$. The aac $\mathrm{C}$ gene (a resistance gene for Aminoglycosides) was reported in this study with a percentage of $33.3 \%$ ( 3 out of 9 isolates) as in Fig. 5. This result differs from Lynne et al. (2008); who reported that $a a c \mathrm{C}$ gene in 5 from 7 isolates with the percentage of $71.4 \%$. The high rate of antimicrobial genes detection in salmonella isolated from human food (chicken meat) consider potential risk for the human health and narrow the available medication choices to human cases in addition to increase the risk of retransmission salmonella species from human to poultry farms through the infected or carrier people engaged with the poultry industry.

Table 5: Numbers and percentages of Salmonella strains exhibiting resistance and sensitivity to various antimicrobial agents.

\begin{tabular}{lcccc}
\hline $\begin{array}{l}\text { Antimicrobial } \\
\text { agent }\end{array}$ & $\begin{array}{l}\text { Number of resistant } \\
\text { strains (NO) }\end{array}$ & $\begin{array}{l}\text { Percentage of } \\
\text { resistance strains }\end{array}$ & $\begin{array}{l}\text { Number of } \\
\text { sensitive strains (NO) }\end{array}$ & $\begin{array}{l}\text { Percentage of } \\
\text { sensitive strains (\%) }\end{array}$ \\
\hline Levofloxacin (Lev) & 3 & 15.8 & 15 & 78.9 \\
Sulfamethazine (Smz) & 19 & 100.0 & 0 & 0.0 \\
Tetracycline(T) & 15 & 78.9 & 4 & 21.1 \\
Amoxicillin (AX) & 15 & 78.9 & 3 & 15.8 \\
Neomycin (N) & 12 & 63.2 & 5 & 26.3 \\
Doxycycline (Do) & 5 & 26.3 & 9 & 47.4 \\
Ciprofloxacin (Cip) & 4 & 21.1 & 11 & 57.9 \\
Chloramphenicol (C) & 8 & 42.1 & 9 & 47.4 \\
Colistin (CL) & 5 & 26.3 & 9 & 47.4 \\
Gentamycin (Cn) & 4 & 21.1 & 15 & 78.9 \\
\hline
\end{tabular}

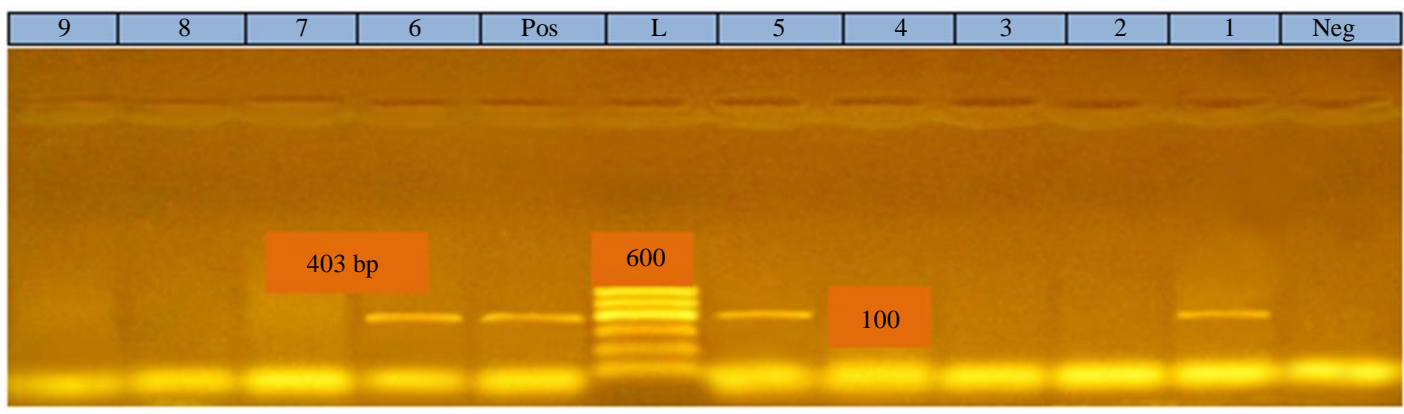

Fig. 1: Agarose gel electrophoresis showing specific PCR of Salmonella strains using primer set for qepA gene (403bp)

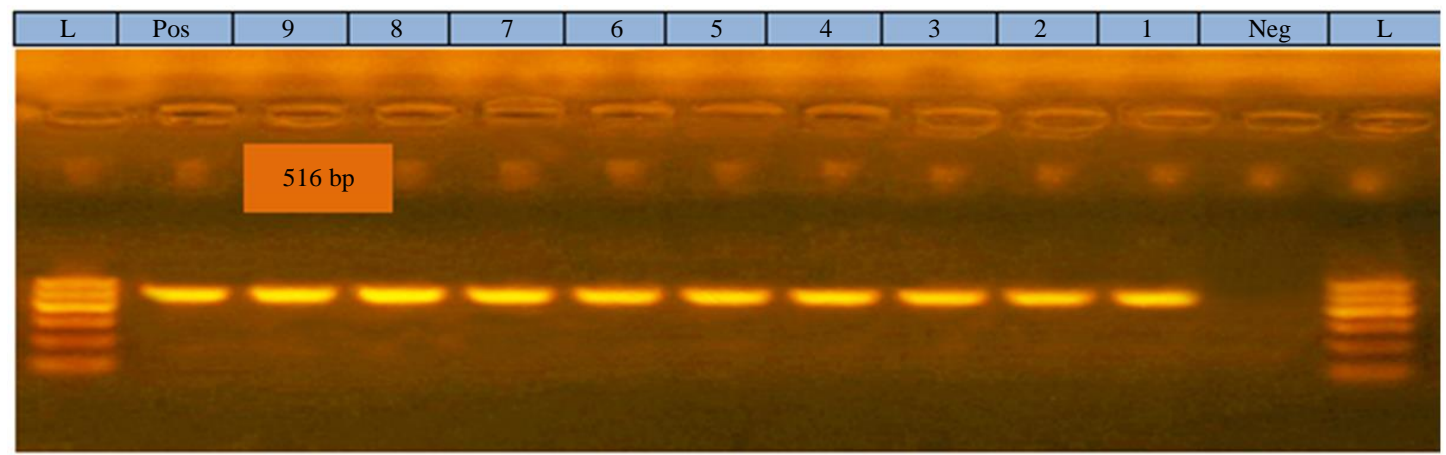

Fig. 2: Agarose gel electrophoresis showing specific PCR of Salmonella strains using primer set for blaTEM gene (516 bp) 


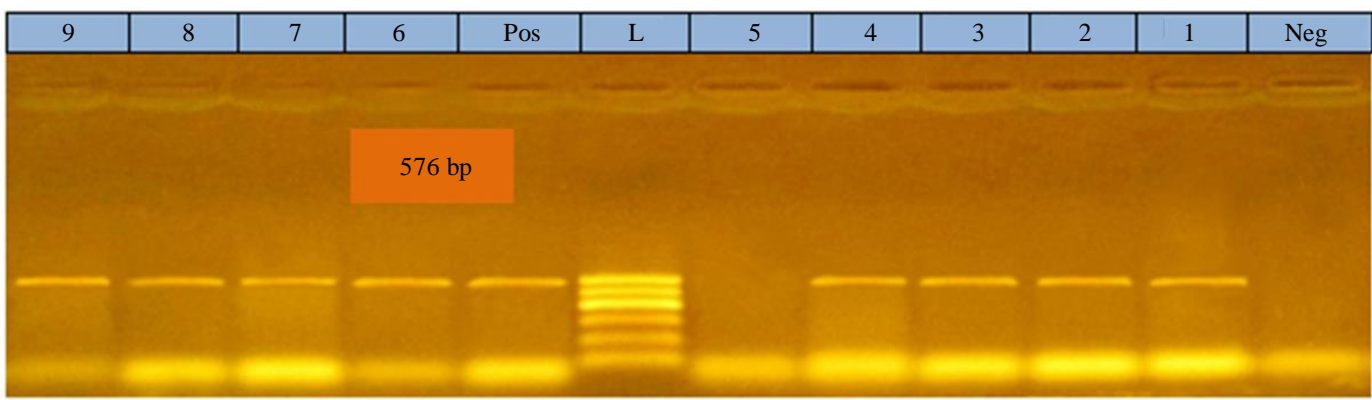

Fig. 3: Agarose gel electrophoresis showing specific PCR of Salmonella strains using primer set for tetA (A) gene (576 bp)

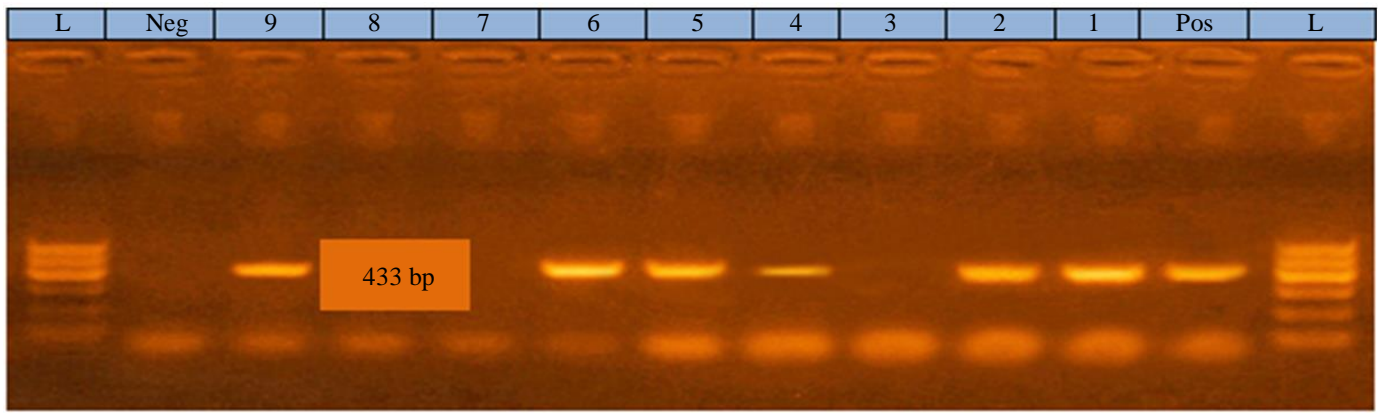

Fig. 4: Agarose gel electrophoresis showing specific PCR of Salmonella strains using primer set for sul1 gene (433 bp)

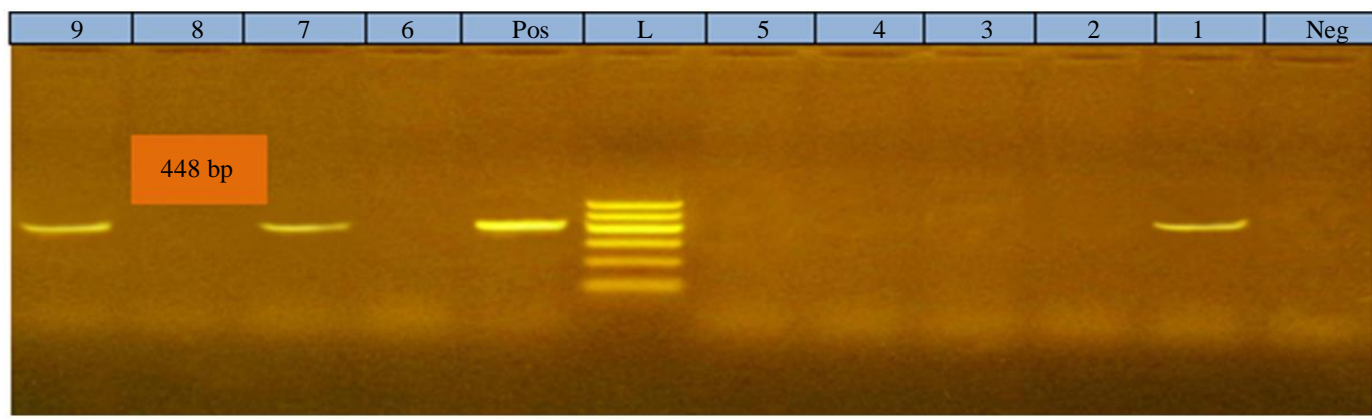

Fig. 5: Agarose gel electrophoresis showing specific PCR of Salmonella strains using primer set for gene aacC (448 bp)

\section{Conclusion}

Salmonellosis is an important global public health problem that has negative effects in poultry industry all over the world. As a result of extensive and in proper usage of antimicrobial agents in human and veterinary medicine specially as growth promotors in poultry feeds, there are dramatically increase in the MDR Salmonella; so that this study was focused on detection of some resistance genes to different antimicrobial agents that used in poultry farms such as qepA for quinolones, sull for sulfonamide, bla TEM for $\beta$ - lactams, aacC for aminoglycosides and tetA (A) for tetracycline. Because of much higher resistance of Salmonellae to different antimicrobial agents that reported in this study using sensitivity tests and PCR it's recommended to use antimicrobial agents in proper dose for recommended time after applying sensitivity tests on the isolated Salmonellae to avoid these resistance that have adverse effect on poultry industry.

\section{Acknowledgment}

All author acknowledge the technical support provided by Dr Hanan Abdien, Avian and Rabbit Medicine Department, Suez Canal University.

\section{Author's Contributions}

All authors equally contributed in this work.

\section{Ethics}

The experiment design approved by the Suez canal university ethical committee. 


\section{References}

Abouelmaatti, R.R., A.M. Algammal, X. Li, J. Ma and E.A. Abdelnaby et al., 2013. Cloning and analysis of Nile tilapia Toll-like receptors type-3 mRNA. Central-European J. Immunol., 38: 277-282. DOI: $10.5114 /$ ceji.2013.37740

Ahmed, A.M. and T. Shimamoto, 2012. Genetic analysis of multiple antimicrobial resistance in Salmonella isolated from diseased broilers in Egypt. Microbiol. Immunol., 56: 254-261.

DOI: $10.1111 / \mathrm{j} .1348-0421.2012 .00429 . \mathrm{x}$

Ahmed, A.M., T. Shimamoto and T. Shimamoto, 2014. Characterization of integrons and resistance genes in multidrug-resistant Salmonella enterica isolated from meat and dairy products in Egypt. Int. J. Food Microbiol., 189: 39-44.

DOI: 10.1016/j.ijfoodmicro.2014.07.031

Ahmed, A.M., E.E. Younis, Y. Ishida and T. Shimamoto, 2009. Genetic basis of multidrug resistance in Salmonella enterica serovars Enteritidis and Typhimurium isolated from diarrheic calves in Egypt. Acta Tropica, 111: 144-149.

DOI: $10.1016 /$ j.actatropica.2009.04.004

Algammal, A. and W. Elfeil, 2015. PCR based detection of Alpha toxin gene in Clostridium perfringens strains isolated from diseased broiler chickens. Benha Vet. Med. J., 29: 333-338.

DOI: $10.21608 /$ bvmj.2015.31744

Aslam, M., S. Checkley, B. Avery, G. Chalmers and V. Bohaychuk et al., 2012. Phenotypic and genetic characterization of antimicrobial resistance in Salmonella serovars isolated from retail meats in Alberta, Canada. Food Microbiol., 32: 110-117. DOI: 10.1016/j.fm.2012.04.017

Authority, E.F.S., 2010. Analysis of the baseline survey on the prevalence of Campylobacter in broiler batches and of Campylobacter and Salmonella on broiler carcasses, in the EU, 2008-Part B: Analysis of factors associated with Campylobacter colonisation of broiler batches and with Campylobacter contamination of broiler carcasses; and investigation of the culture method diagnostic characteristics used to analyse broiler carcass samples. EFSA J., 8: 1522-1522.

DOI: $10.2903 /$ j.efsa.2010.1522

Ayoub, M.A., W.K. Elfeil, D. El Boraey, H. Hammam and M.A. Nossair, 2019. Evaluation of some vaccination programs in protection of experimentally challenged broiler chicken against newcastle disease virus. Am. J. Anim. Vet. Sci., 14: 197-206. DOI: 10.3844/ajavsp.2019.197.206

Bayoumi, A., M. Shahata and I. Sokkar, 1979. Studies on paratyphoid (clinical symptoms, macromorphological, micromorphological) infections of chickens and ducks in Upper Egypt. Assiut Vet. Med. J.
Beli, E., E. Duraku and A. Telo, 2001. Salmonella serotypes isolated from chicken meat in Albania. Int. J. Food Microbiol., 71: 263-266.

DOI: $10.1016 / \mathrm{S} 0168-1605(01) 00613-4$

Capuano, F., A. Mancusi, R. Capparelli, S. Esposito and Y.T. Proroga, 2013. Characterization of drug resistance and virulotypes of Salmonella strains isolated from food and humans. Foodborne Pathog. Dis., 10: 963-968. DOI: 10.1089/fpd.2013.1511

Cattoir, V., L. Poirel and P. Nordmann, 2008. Plasmidmediated quinolone resistance pump QepA2 in an Escherichia coli isolate from France. Antimicrob. Agents Chemother., 52:3801-3804.

DOI: 10.1128/AAC.00638-08

Chenu, J., J. Cox and A. Pavic, 2012. Classification of Salmonella enterica serotypes from Australian poultry using repetitive sequence-based PCR. J. Applied Microbiol., 112: 185-196.

DOI: $10.1111 / \mathrm{j} .1365-2672.2011 .05172 . x$

Cruchaga, S., A. Echeita, A. Aladueña, J. García-Peña and N. Frias et al., 2001. Antimicrobial resistance in salmonellae from humans, food and animals in Spain in 1998. J. Antimicrobial Chemotherapy, 47: 315-321. DOI: 10.1093/jac/47.3.315

Cruickshank, R., 1975. Medical Microbiology: The Practice of Medical Microbiology. 1st Edn., Churchill Livingstone, New York, ISBN-10: 0443011117, pp: 587.

Colom, K., J. Pèrez, R. Alonso, A. Fernández-Aranguiz and E. Lariňo et al., 2003. Simple and reliable multiplex PCR assay for detection of blaTEM, blaSHV and blaOXA-1 genes in Enterobacteriaceae. FEMS Microbiol. Lett., 223: 147-151. DOI: 10.1016/S0378-1097(03)00306-9

de Oliveira, F.A., A. Brandelli and E.C. Tondo, 2006. Antimicrobial resistance in Salmonella enteritidis from foods involved in human salmonellosis outbreaks in southern Brazil. New Microbiol., 29: 49-54.

Diab, M.S., M.S.A.E. Hafez, M.A. Ashry and W.K. Elfeil, 2019. Occurrence of avian influenza h5n1 among chicken, duck farms and human in Egypt. Am. J. Anim. Vet. Sci., 14: 26-32.

DOI: 10.3844 /ajavsp.2019.26.32

Dominguez, S.A. and D.W. Schaffner, 2009. Survival of Salmonella in processed chicken products during frozen storage. J. Food Protect., 72: 2088-2092. DOI: $10.4315 / 0362-028 X-72.10 .2088$

Donado-Godoy, P., V. Clavijo, M. León, A. Arevalo and R. Castellanos et al., 2014. Counts, serovars and antimicrobial resistance phenotypes of Salmonella on raw chicken meat at retail in Colombia. J. Food Protect., 77: 227-235.

DOI: 10.4315/0362-028X.JFP-13-276 
Donado-Godoy, P., V. Clavijo, M. Leon, M.A. Tafur and S. Gonzales et al., 2012. Prevalence of Salmonella on retail broiler chicken meat carcasses in Colombia. J. Food Protect., 75: 1134-1138. DOI: $10.4315 / 0362-028 X . J F P-11-513$

Draz, A., A. El-Gohary and H. Samahy, 1997. Environmental pollution with certain bacterial pathogens of zoonotic importance in some poultry farms. Faculty of Veterinary Medicine, Assiut (Egypt).

Duarte, D.A.M., A.R. Ribeiro, A.M.M. Vasconcelos, S.B. Santos and J.V.D. Silva et al., 2009. Occurrence of Salmonella spp. in broiler chicken carcasses and their susceptibility to antimicrobial agents. Brazilian J. Microbiol., 40: 569-573. DOI: $10.1590 / \mathrm{S} 1517-83822009000300020$

Eid, H.I., A.M. Algammal, S.A. Nasef, W.K. Elfeil and G.H. Mansour, 2016. Genetic variation among avian pathogenic $E$. coli strains isolated from broiler chickens. Asian J. Anim. Vet. Adv., 11: 350-356. DOI: 10.3923/ajava.2016.350.356

Eid, H.M., A.M. Algammal, W.K. Elfeil, F.M. Youssef and S.M. Harb et al., 2019. Prevalence, molecular typing and antimicrobial resistance of bacterial pathogens isolated from ducks. Vet. World, 12: 677-683. DOI: 10.14202/vetworld.2019.677-683

El-Demerdash, M.Z., H.F. Abdien, W.K. Elfeil, S.A. Abdel-Wanis and S.H. Mosalem, 2016. Molecular characterization of salmonella resistant genes in poultry. Proceedings of the 9th International Veterinary Conference on One World, One Health, (CWH' 16).

El-Ghany, W.A.A., S.S. El-Shafii and M. Hatem, 2012. A survey on Salmonella species isolated from chicken flocks in Egypt. Asian J. Anim. Vet. Adv., 7: 489-501. DOI: 10.3923/ajava.2012.489.501

Elfeil, W.K., R.R. Abouelmaatti, C. Sun, W. Han and X. Li et al., 2012. Identification, cloning, expression of a novel functional anasplatyrhynchos mRNA TLR4. J. Anim. Vet. Adv., 11: 1727-1733. DOI: 10.3923/javaa.2012.1727.1733

Elfeil, W.M.K., A.M. Algammal, R.R. Abouelmaatti, A. Gerdouh and M.M. Abdel-Daim, 2016. Molecular characterization and analysis of TLR-1 in rabbit tissues. Central Eur. J. Immunol., 41: 236-242. DOI: $10.5114 /$ ceji.2016.63121

Elhady, M.A., A. Ali, W.H. Kilany, W.K. Elfeil and H. Ibrahim et al., 2018. Field efficacy of an attenuated infectious bronchitis variant 2 virus vaccine in commercial broiler chickens. Vet. Sci., 5: 49-49. DOI: 10.3390/vetsci5020049

Enany, M.E., A.M. Algammal, A.M. Hanora, G.I. Shagar and W.K. Elfeil et al., 2018. Molecular typing and evaluation of sidr honey inhibitory effect on virulence genes of MRSA strains isolated from Catfish in Egypt. Pak. J. Pharmaceutical Sci., 31: 1865-1870.
Ezzat, M., I. Shabana, A. Esawy and M. Elsotohy, 2014. Detection of virulence genes in Salmonella serovars isolated from broilers. Anim. Vet. Sci., 2: 189-193. DOI: $10.11648 /$ j.avs.20140206.16

Finegold, S. and S. Martin, 1982. Diagnostic Microbiology 6th ed the CV Mosby Company, St. Louis Tranto, London. Wiener Tierarstilich Mschr, 6: 233-236.

Foley, S. and A. Lynne, 2008. Food animal-associated Salmonella challenges: Pathogenicity and antimicrobial resistance. J. Anim. Sci., 86: E173-E187. DOI: 10.2527/jas.2007-0447

Hassanein, R., S.F.H. Ali, A. El-Malek, A. Mohamed and M.A. Mohamed et al., 2011. Detection and identification of Salmonella species in minced beef and chicken meats by using Multiplex PCR in Assiut city. Vet. World, 4: 5-11. DOI: $10.5455 /$ vetworld.2011.5-11

Hui, Y.Z., 2015. Serotypes and antimicrobial susceptibility of Salmonella spp. isolated from farm animals in China. Front Microbiol., 6: 602-602. DOI: $10.3389 /$ fmicb.2015.00602

Huong, L.Q., F. Reinhard, P. Padungtod, T.T. Hanh and M.N. Kyule et al., 2006. Prevalence of Salmonella in retail chicken meat in Hanoi, Vietnam. Ann. NY Acad. Sci., 1081: 257-261.

DOI: 10.1196/annals.1373.032

Hur, J., J.H. Kim, J.H. Park, Y.J. Lee and J.H. Lee, 2011. Molecular and virulence characteristics of multidrug resistant Salmonella Enteritidis strains isolated from poultry. Vet. J., 189: 306-311.

DOI: $10.1016 /$ j.tvjl.2010.07.017

Hyeon, J.Y., J.W. Chon, I.G. Hwang, H.S. Kwak and M.S. Kim et al., 2011. Prevalence, antibiotic resistance and molecular characterization of Salmonella serovars in retail meat products. J. Food Protect., 74: 161-166.

DOI: 10.4315/0362-028X.JFP-10-327

Ibekwe, A.M., S.E. Murinda and A.K. Graves, 2011. Genetic diversity and antimicrobial resistance of escherichia coli from human and animal sources uncovers multiple resistances from human sources. PLoS ONE, 6: e20819-e20819. DOI: 10.1371/journal.pone.0020819

Ibrahim, M., H. Emeash, N.H. Ghoneim and M. AbdelHalim, 2013. Seroepidemiological studies on poultry salmonellosis and its public health importance. J. World's Poult. Res., 3: 18-23.

Kauffmann, F., 1972. Serological Diagnosis of Salmonella-Species. 1st Edn., Munksgaard, Copenhagen, pp: 125.

Kaushik, P., S. Kumari, S.K. Bharti and S. Dayal, 2014. Isolation and prevalence of Salmonella from chicken meat and cattle milk collected from local markets of Patna, India. Vet. World, 7: 62-65.

DOI: $10.14202 /$ vetworld.2014.62-65 
Kozačinski, L., M. Hadžiosmanović and N. Zdolec, 2006. Microbiological quality of poultry meat on the Croatian market. Veterinarski Arhiv, 76: 305-313.

Le Bouquin, S., V. Allain, S. Rouxel, I. Petetin and M. Picherot et al., 2010. Prevalence and risk factors for Salmonella spp. contamination in French broilerchicken flocks at the end of the rearing period. Prev. Vet. Med., 97: 245-251.

DOI: 10.1016/j.prevetmed.2010.09.014

Lunn, A.D., A. Fàbrega, J. Sánchez-Céspedes and J. Vila, 2010. Prevalence of mechanisms decreasing quinolone-susceptibility among Salmonella spp. clinical isolates. Int. Microbiol., 13: 15-20.

Lynne, A.M., B.S. Rhodes-Clark, K. Bliven, S. Zhao and S.L. Foley, 2008. Antimicrobial resistance genes associated with Salmonella enterica serovar newport isolates from food animals. Antimicrob Agents Chemother, 52: 353-356.

DOI: 10.1128/AAC.00842-07

Medeiros, M.A.N., D.C.N. Oliveira, D.P. Rodrigues and D.R.C. Freitas, 2011. Prevalence and antimicrobial resistance of Salmonella in chicken carcasses at retail in 15 Brazilian cities. Revista Panamericana Salud Pंblica, 30: 555-560.

DOI: $10.1590 /$ S1020-49892011001200010

Moawad, A., 2009. Bacteriological studies on Salmonella Enteritidis isolated from different sources in Dakhlia Governorate. Zoonoses, Veterinary Medicine, Mansoura University.

Mosalem, S., 2016. Studies on salmonella infection in chickens and it's relation to molecular characters. Department of Avian and Rabbit Medicine, Suezcanal University, Egypt.

Murugkar, H., H. Rahman, A. Kumar and D. Bhattacharyya, 2005. Isolation, phage typing and antibiogram of Salmonella from man and animals in northeastern India. Indian J. Med. Res., 122: 237-237.

Nabil, N.M. and A.E. Yonis, 2019. Isolation of salmonella characterized by biofilm formation and disinfectant resistance from broiler chickens. Alexandria J. Vet. Sci., 62: 26-36.

DOI: $10.5455 /$ ajvs.57274

Rabie, N.S., N.O. Khalifa, M.E. Radwan and J.S. Afify, 2012. Epidemiological and molecular studies of Salmonella isolates from chicken, chicken meat and human in Toukh, Egypt. Global Vet., 8: 128-32.

Randall, L.P., S.W. Cooles, M.K. Osborn, L.J.V. Piddock and M.J. Woodward, 2004. Antibiotic resistance genes, integrons and multiple antibiotic resistance in thirty-five serotypes of Salmonella enterica isolated from humans and animals in the UK. J. Antimicrobial Chemotherapy, 53: 208-216. DOI: $10.1093 / \mathrm{jac} / \mathrm{dkh} 070$
Ruban, S., M. Thiyageeswaran and R. Sharadha, 2010. Isolation and identification of Salmonella spp. from retail chicken meat by polymerase chain reaction. Int. J. Microbiol. Res., 1: 106-109.

Sadoma, A., 1997. Salmonella in chickens in connection with human infection. Veterinary Medicine, Tanta Univerisity, Egypt.

Sedeik, M.E., A.M. Awad, H. Rashed and W.K. Elfeil, 2018. Variations in pathogenicity and molecular characterization of Infectious Bursal Disease Virus (IBDV) in Egypt. Am. J. Anim. Vet. Sci., 13: 76-86. DOI: 10.3844/ajavsp.2018.76.86

Sedeik, M.E., A. Nahed, A.M. Awad, H.S. Abd-Elhamid and H.F. Ellakany et al., 2019. Identifying intraspecific variability in the virulence of Eimeria tenella using SCAR markers. Poult. Sci., 18: 151-158. DOI: 10.3923/ijps.2019.151.158

Shahada, F., T. Chuma, T. Tobata, K. Okamoto and M. Sueyoshi et al., 2006. Molecular epidemiology of antimicrobial resistance among Salmonella enterica serovar infantis from poultry in Kagoshima, Japan. Int. J. Antimicrobial Agents, 28: 302-307.

DOI: 10.1016/j.ijantimicag.2006.07.003

Silva-Sanchez, J., H. Barrios, F. Reyna-Flores, M. BelloDiaz and A Sanchez-Perez et al., 2011. Prevalence and characterization of plasmid-mediated quinolone Resistance genes in extended-Spectrum $\beta$ lactamase-producing Enterobacteriaceae isolates in Mexico. Microbial. Drug Resistance, 17: 497-505. DOI: $10.1089 / \mathrm{mdr} .2011 .0086$

Sodagari, H.R., Z. Mashak and A. Ghadimianazar, 2015. Prevalence and antimicrobial resistance of Salmonella serotypes isolated from retail chicken meat and giblets in Iran. J. Infect. Dev. Countries, 9: 463-469. DOI: 10.3855/jidc.5945

Soomro, A.H., M. Khaskheli, M.B. Bhutto, G. Shah and A. Memon et al., 2011. Prevalence and antimicrobial resistance of Salmonella serovars isolated from poultry meat in Hyderabad, Pakistan. Turk. J. Vet. Anim. Sci., 34: 455-460.

Sultan, H.A., A. Ali, W.K. El Feil, A.H.I. Bazid and M.A. Zain El-Abideen et al., 2019a. Protective efficacy of different live attenuated infectious bronchitis virus vaccination regimes against challenge with IBV variant-2 circulating in the Middle East. Frontiers Vet. Sci., 6: 341-341.

DOI: 10.3389/fvets.2019.00341

Sultan, H.A., A.E. Arafa, S. Talaat, A.A. Gaballa and W.H. Kilany et al., 2019b. Efficacy of clade 2.3.2 H5-recombinant baculovirus vaccine in protecting Muscovy and Pekin ducks from Clade 2.3.4.4 H5N8 highly pathogenic avian influenza infection. Avian Dis., 63: 219-229. DOI: 10.1637/11880-042718.1 
Taha, N., 1989. Epidemiological studies on animal pathogens causing infantile diarrhea in Sharkia Governorate. Microbiology, Veterinary Medicine, Zagazig Univerisity, Egypt.

Van, T.T.H., G. Moutafis, L.T. Tran and P.J. Coloe, 2007. Antibiotic resistance in food-borne bacterial contaminants in Vietnam. Applied Environ. Microbiol., 73: 7906-7911. DOI: 10.1128/AEM.00973-07

White, D.G., S. Zhao, R. Sudler, S. Ayers and S. Friedman et al., 2001. The isolation of antibioticresistant Salmonella from retail ground meats. New England J. Med., 345: 1147-1154. DOI: $10.1056 /$ NEJMoa010315

WHO, 2004. Second joint FAO/OIE/WHO expert workshop on non-human antimicrobial usage and antimicrobial resistance: Management options: 1518 March 2004, Oslo, Norway. World Health Organization, Geneva.

WHO, 2007. Critically important antimicrobials for human medicine: categorization for the development of risk management strategies to contain antimicrobial resistance due to non-human antimicrobial use: Report of the second WHO Expert Meeting. Copenhagen, Denmark.
Yang, B., D. Qu, J. Shen, M. Xi and S. Zhi et al., 2010. Antimicrobial susceptibility and related genes of Salmonella serovars from retail food in Shaanxi province. Wei Sheng Wu Xue Bao, 50: 788-796. PMID: 20687345

Yang, S.J., K.Y. Park, S.H. Kim, K.M. No and T.E. Besser et al., 2002. Antimicrobial resistance in Salmonella enterica serovars Enteritidis and Typhimurium isolated from animals in Korea: Comparison of phenotypic and genotypic resistance characterization. Vet. Microbiol., 86: 295-301. DOI: 10.1016/S0378-1135(02)00009-3

Zhang, C., Y. Ning, L. Song, H. Chen and R. Chen, 2011. Investigation of resistance to tetracycline and distribution of tetracycline resistance genes of Salmonella isolates from poultry. China Poultry, 33: 18-21.

Zou, W., J. Frye, C.W. Chang, J. Liu and C. Cerniglia et al., 2009. Microarray analysis of antimicrobial resistance genes in Salmonella enterica from preharvest poultry environment. J. Applied Microbiol., 107: 906-914.

DOI: $10.1111 / \mathrm{j} .1365-2672.2009 .04270 . x$ 